\title{
Сагаласс - «Первый город Писидии»: к истории регионального центра римской Малой Азии
}

\author{
Болгов Н.Н. ${ }^{\text {, Елисеева А.Ю. }}{ }^{2}$ \\ ${ }^{1)}$ Белгородский государственный национальный исследовательский университет, \\ Россия, 308007, г. Белгород, ул. Студенческая, 14; \\ ${ }^{2)}$ Белгородский государственный историко-краеведческий музей, \\ Россия, 308600, г. Белгород, ул. Попова, 2а \\ E-mail: bolgov@bsu.edu.ru; arics_06@mail.ru
}

\begin{abstract}
Аннотация. В работе освещается история и современное состояние изучения малоазийского города Сагаласс как регионального центра в Писидии - горной области в южной части Малой Азии. Выделяются исторические этапы жизни города - доантичный, эллинистический, римский. Специально анализируется римский период истории города, преимущественно на основании материальной культуры, в силу характера сохранившихся памятников. Подчеркивается важный характер комплексного исследования города, осуществляемого бельгийской командой ученых из Лёвенского университета. Дается краткий обзор научной библиографии по истории Сагаласса, насчитывающий на данный момент более 120 наименований и 7 специальных сборников материалов «Сагаласс» (с 1993 г.). Делается вывод о том, что Сагаласс - один из наиболее изученных сегодня городов юга Малой Азии. Вместе с тем регионы античной Малой Азии нуждаются в изучении в отечественной историографии.
\end{abstract}

Ключевые слова. Сагаласс, Малая Азия, Рим, Писидия, регион, колонизация, провинция.

Для цитирования: Болгов Н.Н., Елисеева А.Ю. 2021. Сагаласс - «Первый город Писидии»: к истории регионального центра римской Малой Азии. Via in tempore. История. Политология, 48 (3): 579-596. DOI 10.52575/2687-0967-2021-48-3-579-596.

\section{Sagalassos - «The first city of Pisidia»: to the history of the regional center of Roman Asia minor}

\author{
Nikolay N. Bolgov ${ }^{1}$, Anastasia Yu. Eliseeva ${ }^{2}$ \\ 1) Belgorod National Research University, \\ 14 Studencheskaja St., Belgorod, 308007, Russia; \\ ${ }^{2)}$ Belgorod State Museum of History and Local Lore, \\ 2a Popova St., Belgorod, 308600, Russia \\ E-mail: bolgov@bsu.edu.ru; arics_06@mail.ru
}

\begin{abstract}
The paper highlights the history and current state of the study of the Asia Minor city of Sagalass as a regional center in Pisidia - a mountainous region in the southern part of Asia Minor. The historical stages of the city's life are highlighted - pre-antique, Hellenistic, Roman. The Roman period of the city's history is specially analyzed, mainly on the basis of material culture, due to the nature of the preserved monuments. The situation with the loss of the rank of «the first city of Pisidia» by Sagalass in connection with the formation of the province of the same name, where Antioch became the capital, is assessed. In return, Sagalass received alternative accolades that preserved it as the region's informal center. The important character of the complex study of the monument, carried out by the Belgian team of scientists from the University of Louvain, is emphasized. A brief overview of the scientific bibliography on the history of Sagalass is given, which currently has more than 120 titles and 7 special collections of materials «Sagalass» (since 1993).
\end{abstract}


Keywords. Sagalassus, Asia Minor, Rome, Pisidia, region, colonization, province.

For citation: Bolgov N.N., Eliseeva A.Yu. 2021. Sagalassos - «The first city of Pisidia»: to the history of the regional center of Roman Asia minor. Via in tempore. History and political science, 48 (3): 579-596 (in Russian). DOI 10.52575/2687-0967-2021-48-3-579-596.

\section{Введение}

Нет нужды говорить о том, сколь обширное количество наших соотечественников за последние два-три десятилетия посетили Турцию в качестве туристов и отдыхающих. Конечно, среди них присутствовали и профессиональные антиковеды, византинисты и археологи, которые смогли ознакомиться с работами коллег на памятниках античной и византийской Малой Азии. Однако предметом профессионального исторического осмысления за это время регион так и не стал. В отечественной историографии не появилось ни одной диссертации или крупной научной работы такого рода, в отличие от многочисленных «археологических путешествий» заинтересованных дилетантов или паломников, которые зачастую почти исчерпывающе представляют фотоматериалы о памятниках, что может служить дополнительным исходным материалом помимо аутопсии для профессионалов.

Между тем Малая Азия содержит огромное количество памятников самого первого ряда, знакомство с которыми необходимо для специалиста, как и ознакомление с историографической ситуацией для понимания картины и масштаба археологических работ в Турции начиная с послевоенного времени.

В январе 2021 г. возможность такой ознакомительной поездки представилась небольшой группе ученых кафедры всеобщей истории НИУ «БелГУ». В ее ходе удалось посетить до десятка городищ на юге Малой Азии - в Памфилии, Писидии, Ликии и южной Фригии. Последующее целенаправленное ознакомление с историографией позволило создать общее впечатление о степени изученности вопроса и выделить основные объекты для последующего изучения.

\section{Результаты и их обсуждение}

В силу распределения современных транспортных путей, наиболее близким для отечественного вояжера историческим регионом Малой Азии является Памфилия. Ее городами уже начали заниматься представители нашей научной группы [Прокопенко, 2018; Prokopenko, 2021]. Но не меньший интерес представляет соседняя с ней Писидия - один из наименее интересовавших отечественное антиковедение регионов юга (юго-запада) Малой Азии ${ }^{40}$.

Писидия не имеет выхода к морю, и ее основные внешние коммуникации осуществлялись через Памфилию, расположенную южнее (порты Атталия и Сиде). Главная характеристика Писидии - это горная страна с не очень устойчивыми административными границами, которые часто не совпадали с историческими [Болгов, 2021, с. 98].

Писидию можно разделить на микрорегионы. Юго-восток Писидии - район Сельге, примыкающий к Исаврии и горам Тавра. Юго-западная часть Писидии с центром в Термессе административно никогда не входила в одноименную провинцию. Центральная часть Писидии - внутренний горный район между озерами с городами Сагаласс и Кремна (рис. 1).

40 Западом Малой Азии можно назвать эгейские провинции от Мисии (Троады) до Карии включительно. Памфилия, Писидия и Ликия могут быть названы как юго-западными (такое название принято в западном антиковедении, имея в виду скорее юго-запад современной Турции), так и южными (средиземноморскими) - по принятому ныне в Турции историко-географическому районированию. Расположенные к востоку от названных провинций Исаврия и Киликия охватывают уже юго-восток собственно полуострова Малая Азия (горы Тавра). 


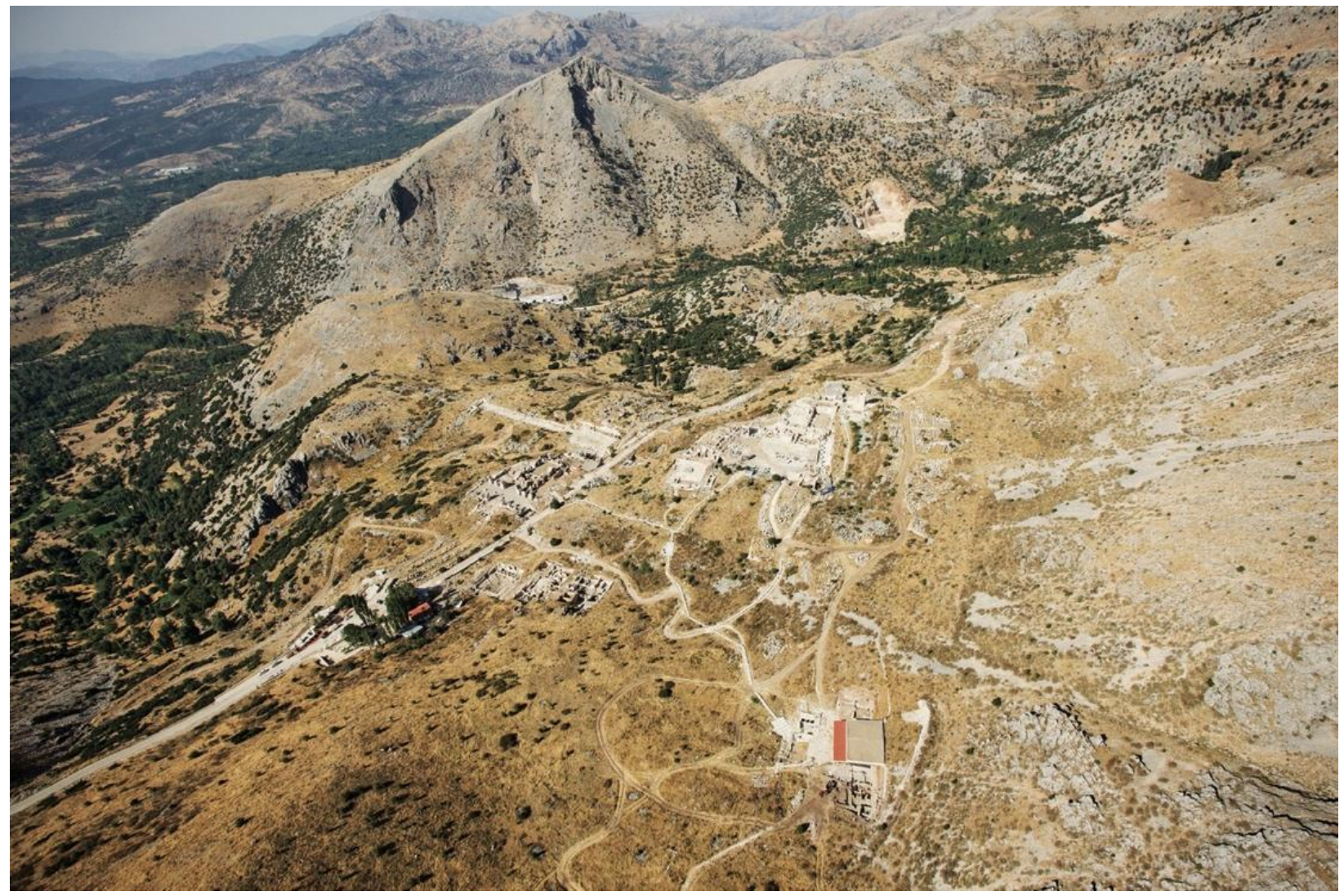

Рис. 1. Сагаласс, вид с воздуха на верхнюю и нижнюю части города (Археологический исследовательский проект Сагаласса)

Fig. 1. Sagalassos, aerial view of the upper and lower parts of the city (Sagalassos Archaeological Research Project) [Poblome, Talloen, Kaptijn, 2017, p. 303].

Север Писидии - большая равнина между озерами Эгирдир и Акшехир со столицей провинции - Антиохией Писидийской, а также Филомелием. Северо-запад - к северу от озера Асконий (Бурдур) и к западу от озера Эгирдир - граничит с Фригией и имеет множество городов во главе с Апамеей Кибот; некоторое время она административно входила в провинцию Писидия. Северо-восток региона - Лаодикея Катакекавмена - административно часть провинции Писидия в V в., порой доходя до огромного соленого озера Татта (Туз), но исторически - скорее северная часть Ликаонии на стыке Галатии [Болгов, 2021, с. 98-99].

Писидия представляла собой гористую область у западных отрогов Тавра с отдельными плато и равниной на севере. Горы были частично покрыты лесами. Писидия считалась достаточно засушливой страной, водой ее обеспечивали горные источники и довольно частые сильные дожди, а также озера. Через Писидию проходили важные дороги, связывавшие Эгейский регион с юго-востоком Малой Азии. Вместе с тем горный характер страны был не настолько суров, как в соседней Исаврии.

Важнейшим городом Писидии, наиболее полно передающим ее историческую специфику, является Сагаласс, находящийся в самом сердце страны.

Как отмечает Барбара Левик, в римской политике понятие «Писидия» активно появляется при Августе, который утверждал, что он основал колонии в Писидии [Levick, 1967, p. 33]. В то время Писидия, в отличие от других областей, не была собственно провинцией и фактически не являлась ею вплоть до реорганизации, проведенной Диоклетианом. Тем не менее это был четко определенный регион, за исключением, возможно, восточной стороны, которая сливалась с собственно хребтом Тавра [Levick, 1967, p. 33].

Новая административная организация империи, предпринятая Диоклетианом, привела к созданию провинции Писидия, состоящей из Фригии Парории и северной части ис- 
торической области Писидия. При этом, как уже отмечалось, некоторые важные территории Писидии, например, юго-запад, в состав одноименной провинции не вошли.

Столицей новой провинции стала колония Августа Антиохия ${ }^{41}$, но Сагаласс в большой мере сохранил неформальный статус «первого города Писидии», вес и авторитет регионального центра и оставался городом с хорошими связями и влиянием по всей югозападной Малой Азии вплоть до VII в. ${ }^{42}$

Местоположение Сагаласса. Один из четырех хребтов Писидии, начинающийся в Ликии в долине между Ксанфом и Антифеллом, продолжается почти непрерывно до Сагаласса, затем спадает и снова появляется на высотах между Тимандом и Аграми. Сагаласс расположен на одном из главных гребней этого хребта (рис. 2).

\section{A Walk Through Sagalassos}
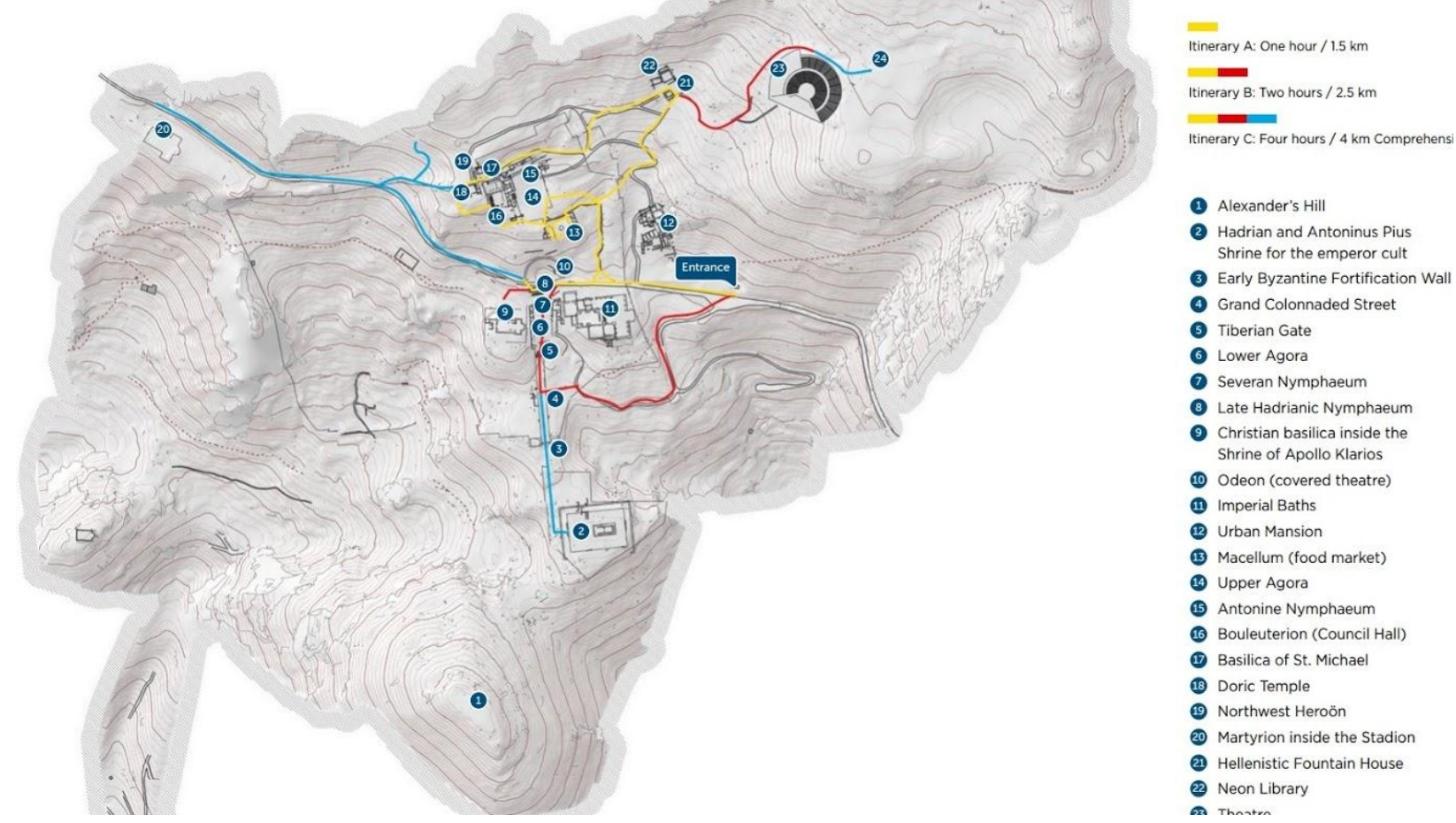

Рис. 2. Сагаласс. Маршрут туристического осмотра

Fig. 2. Sagalassos. Tourist sightseeing route

Последний участок хребта отрезан от остальной части рекой Кестр, которая изгибается от Сагаласса до Бариса и далее уходит на юг в Памфилию. Приток реки Лисий отделял Сагаласс от Тимбрианы.

Древняя дорога с юга на север пролегала через Дошеме и Ариасс, через равнину Кестель-Галь к Сагалассу, таким образом соединяя Памфилию напрямую с Барисом и Селевкией Сидерой, а затем - с Апамеей и Аполлонией. Это был путь Александра Македонского [Levick, 1967, p. 15].

Основные вехи истории Сагаласса. Сагаласс был известен как город еще с IV в. до н. э. Однако, по всей видимости, доантичное поселение на этом месте существовало

${ }^{41}$ Название этого города обычно дается как Антиохия Писидийская. Однако Б. Левик уточняет это, считая, что правильнее называть город «Антиохия в сторону Писидии», «Антиохия, лежащая по направлению к Писидии» - как бы глядя из Фригии, откуда двигалось колонизационное движение [Levick, 1967, p. 18].

42 Общий обзор позднеантичного Сагаласса см.: [Waelkens et al., 2006, p. 199-256]. 
значительно ранее; его следы сохранились в названии Салавасса из хеттских источников XIV в. до н. э.

Сагаласс, как и Сельге, в своей исторической традиции связывал начало своей античной истории с легендарными временами и родстве с лакедемонянами (Arr. Anab. I. 28. II) ${ }^{43}$, но это - лишь часто встречающаяся «привязка» к ранней истории, не имеющая исторических оснований.

В 333 г. до н. э. город был завоеван Александром Македонским. После покорения Памфилии он двинулся из Перге мимо Термесса на Сагаласс (Arr. Anab. I, 28, 2, 5-6), который, как отмечал И.Г. Дройзен, был «населен самыми воинственными из всех писидов, лежал у подножия верхней террасы писидийской горной страны и открывал доступ в возвышенную равнину Фригии» [Дройзен, 1997, т. 1, с. 109]. Город был взят штурмом с большим трудом. После падения Сагаласса остальные местечки Писидии были или взяты силой или сдались. Таким образом открылся путь на возвышенную равнину, с которой начинается Фригия по ту сторону горы Сагаласса.

В эпоху диадохов Писидия отошла к Селевкидам. В результате изгнания Манлием Вульсоном гарнизона Селевкидов из Перге в 189 г. до н. э., Эвмен Пергамский получил Памфилию, за исключением всех важных городов Юго-Запада, которые Манлий признал свободными [Ранович, 1950, с. 265]. Некоторые внутренние города также были свободны от власти Евмена. Безусловно, в этот список входила Антиохия и, скорее всего, Сагаласс (Plin. HN 710; IGR III. 348, 350-353) и Сельге (Plin. HN 711f.; Strabo XII, 571; Trog., Prot. XXXIV). Менее уверенно это можно говорить о Термессе (ILS 38, Lex Antonia de Termessensibus).

К 188 г. до н. э. городская территория Сагаласса достигла юго-западной части равнины Бурдур на западе (Liv. XXXVIII. 15; Polib. XXI. 36. 3-4) и реки Кестр на востоке. В конечном итоге она охватила территорию в 1200 км². $^{2}$

Фактическая власть римлян впервые устанавливается здесь в конце I в. до н. э., но в 39-25 гг. до н. э. Писидия включается в клиентское царство Аминты (36-25 гг. до н. э.). Юго-западные пределы этого государственного образования определяются тем, что в него были включены Сагаласс и Сельге. Вторую, более реальную аннексию осуществляет здесь уже Август [Magie, 1950].

В первые века н. э. Писидия непосредственно подчинялась императору, в ней были размещены легионы для оперативных действий. Административно территория Писидии в первые века н. э. входила в состав нескольких провинций - это Ликия-Памфилия, Галатия и Фригия [Jones, 1971].

Римляне уже при Августе вывели в Писидию 8 колоний; при этом первоначально они не вывели колонию в Сагаласс, предпочтя ему достаточно близко к нему расположенную Кремну. Кремна была выбрана как наиболее подходящее место для римской колонии (а не более важный Сагаласс, расположенный севернее того же хребта), по всей видимости, потому что Кремна была «не разграбленным» городом-крепостью, который должен был стать опорным пунктом римского владычества ${ }^{44}$. Наиболее важные и развитые старые города Писидии не были выбраны в качестве мест для колонизации.

Протейя, метрополия, неокория. В римский период, в течение II - 1-й пол. III в. Сагаласс переживал время наивысшего расцвета, когда были возведены основные памятники материальной культуры, составляющие и сегодня архитектурный облик городища.

Будучи расположенным в самом центре этнической Писидии, город всегда считался ее неформальной столицей. Со временем этот статус стал и официальным. Почетный

\footnotetext{
43 По поводу притязаний на родство с лакедемонянами см.: [Woodward, 1953, p. 868ff.].

${ }^{44}$ Некоторые авторы подчеркивают роль Кремны еще и как центра коммуникаций региона, подчеркивая ее господство над долиной Кестра в его верховьях.
} 
титул, признавший Сагаласс «первым городом писидийцев» (протейя) в «провинции Ликии и Памфилии» город получил в первые годы правления Адриана [Waelkens, 2011].

В то же время Сагаласс был также признан и центром императорского культа в Писидии [Waelkens, 2015, p. 177-214]. Многие города Малой Азии этого времени стремились получить звание неокоров (блюстителей храмов императорского культа), которое предоставлял римский сенат [Burrell, 2004]. Некоторые города получали это звание по два и по три раза, в зависимости от числа храмов, посвященных культу императоров [Свенцицкая, 1981, с. 33-51].

Тот факт, что информация о протейе Сагаласса в Писидии была найдена в строительной надписи храма Антонина Пия, почти наверняка означает, что он был признан таковым Адрианом вскоре после передачи его в состав провинции Ликии и Памфилии. Поскольку его лидерство среди всех городов (этнической) Писидии тогда, несомненно, было бесспорным и, за исключением периода, начавшегося во второй половине правления Констанция II, очевидно, всегда оставалось таковым, эта протейя прямо упоминала и об обладании городом неокорией Писидии, что в публичных надписях в городе было излишним. Таким образом, это первое появление названия протейя в надписи на здании храма можно связать с провозглашением Сагаласса неокором региона в тот же момент времени.

Статус Сагаласса как «первого города Писидии» был поставлен под сомнение между 308 и 311 гг., когда в рамках административной реорганизации империи Диоклетиан выбрал город во Фригии Парории - «Антиохию близ Писидии», крупнейшую колонию Рима в Малой Азии, в качестве столицы вновь созданной провинции Писидия [Waelkens, 2005]. Новая провинция состояла из Фригии Парории и Северной Писидии. После этого протейя Сагаласса в (этнической) Писидии постепенно становилась менее очевидной и в конечном итоге не позднее 354 г., стала неприемлемой для Антиохии Писидийской, что привело к отмене данного титула.

Однако Констанций II, по всей видимости, для компенсации, понимая важнейшую роль Сагаласса в регионе, почти сразу же предоставил городу новый титул - метрополии: в двух идентичных надписях, вырезанных на двух основаниях статуи Констанция II, датированных 354-361 гг., город называет себя «благородным мегаполисом сагалассцев». За это благодеяние Констанций был очень популярен в Сагалассе в дальнейшем ${ }^{45}$. Хотя этот титул был очень престижным, он все же является вторичным по сравнению с признанием «первым городом» определенного региона. Поэтому вскоре после этого или в течение 1-й пол. V в. Сагаласс объявил себя «метрополией, первым [городом] и корифеем Писидии», объединив старый и новый титулы (протейя и метрополия) и добавив еще один (корифей - предводитель). Кроме того, только в этот период Сагаласс впервые сам назвал себя неокором в надписях, датируемых от правления Диоклетиана до правления Констанция II [Waelkens, 2015].

В еще одной надписи на базе статуи, которая первоначально олицетворяла договор Согласия между Сагалассом и Иконием, город был назван «метрополией сагалассцев и корифеем Писидии, другом и союзником римлян». Датировка этой надписи устанавливается по эпиграмме, вырезанной на другой стороне пьедестала, где во вторичном использовании был изображен некий Зенон. Это может быть император Зенон (474-484 гг.) или Флавий Зенон, magister militum per orientem (447-451 гг.) [Waelkens, 2015].

45 Когда около 500 г. произошло разрушительное землетрясение, Констанций II был единственным императором, чья статуя на Верхней Агоре не была убрана с этой площади после катастрофы, кроме статуи Каракаллы, который в 212 г. предоставил римское гражданство всем свободным жителям Империи. После этого события две статуи Констанция II были установлены вдоль восточной стороны площади с надписями (датируемыми 354-361 гг.) с новым титулом города, и высокая почетная колонна в юго-западном углу площади, первоначально посвященная Кратеру, предку самой известной семьи Сагаласса, была заменена статуей Констанция II. 
В отличие от провинций Памфилия или Азия, где были города, конкурирующие за титул первого города провинции или даже неокорию, положение Сагаласса в Писидии, за исключением некоторого интервала после 346 г., оставалось бесспорным. Оставаясь «первым городом» этого региона на протяжении большей части его римской истории, начиная co 2-й четверти II в. жители Сагаласса, возможно, испытывали даже большую гордость от протейи, нежели от неокории.

Титул «первого города» встречается и в «частных» надписях. Между 211 и 222 гг. автор посвящения Геллию Максиму описывает себя как гражданина Сагаласса - «первого и самого прекрасного города в Писидии» (JRS II (1912), 95 f., № 25).

Город воздвиг десятки почетных статуй в честь граждан, которые в конечном итоге заполнили обе городские площади и выстроились вдоль улицы с колоннами.

Правление Траяна (98-117 гг.) положило начало столетнему строительному буму, пика которого достигли Адриан, Антонин Пий и Марк Аврелий. Эта неистовая строительная деятельность была вызвана тем фактом, что в 117-118 гг. Адриан включил северную Писидию в провинцию Ликию и Памфилию, объединив ее с остальной частью Писидии, и признал Сагаласс в качестве неокора, то есть официального центра императорского культа, исповедуемого всеми писидийцами.

Как неокор Писидии, Сагаласс проводил фестивали и игры, ежегодно собирая посетителей и делегации со всей Писидии. Это принесло городу дополнительный доход и потребовало строительства зданий, размер которых намного превосходил местные потребности.

Сагаласс постоянно называл себя в римское время «первым» городом в Писидии (JRS II (1912), 96 f., № 25). Но в реальности город с III в. находился уже в стороне от мейнстрима малоазийских дел.

Ранневизантийский период. В течение IV в. Сагаласс стал третьим по величине епископством провинции Писидия после фригийских епископств Антиохии и Филомелия; первый документально подтвержденный епископ присутствовал на Константинопольском соборе в 381 г.

Христианство стало со временем господствующей религией в Сагалассе, но классическая культура оставалась глубоко укорененной в обществе вплоть до VI в. Фактически, несмотря на учреждение должности епископа к концу IV в., материальная культура не показывает никаких признаков того, что христианство в то время оказало решительное влияние на город. Языческие храмы были оставлены и заброшены, но не разрушены; их последующее перепрофилирование обеспечило их сохранение до конца античности. Помимо разрушения библиотеки Неона, нет никаких свидетельств того, что столкновения на религиозной почве приводили к погромам и пожарам.

Оживление исавров и возобновление разбойничьих набегов к концу IV в. сделало ситуацию здесь неспокойной и привлекло внимание центральных властей. Иоанн Златоуст, возможно, несколько преувеличивает, когда очень часто пишет в своих письмах о беспокойстве со стороны исавров на всем пространстве Малой Азии. Особенно известен эпизод с деятельностью разбойника Лидия (в описании Зосима), который сделал своей базой Кремну (Zos., I, 69). Кроме того, поблизости, в Сельге, происходили события, связанные с восстанием Трибигильда (Zos., V, 15-16). Оба города расположены достаточно близко от Сагаласса.

C V в. внешняя ситуация в регионе снова стабилизировалась вплоть до арабских набегов в середине VII в. [Waelkens, Jacobs, 2014].

IV-VI века представляли собой новый период роста сельской территории Сагаласса. Количество и размер деревень увеличились в результате интенсификации сельского хозяйства и более специализированного ремесленного и сельскохозяйственного ландшафта, что, возможно, отражает рост сельской демографии.

В течение 1-й половины VI в. многие здания по всему городу были почти полностью перестроены, что повлияло на городскую инфраструктуру. Дата и характер этих пе- 
рестроений предполагают ремонт после какого-то катастрофического события, скорее всего, землетрясения, которое вызвало обширные работы вскоре после 500 г.

Новое землетрясение, которое практически уничтожило Сагаласс как город, произошло в начале VII в. или вскоре после него. Об этом свидетельствуют необратимые изменения в характере организации городской жизни. В конце VI и VII вв. утилизация отходов больше не организовывалась на муниципальном уровне. Бассейны некоторых нимфейонов, коридоры и сцена бывшего Одеона, заброшенные лавки у Нижней Агоры и Колоннадной улицы стали свалками для отходов. Части территории Мацеллума использовались до начала VII в. в том числе как мастерские. C середины VI в. северная часть территории рынка использовалась как свалка. Системы водоснабжения и канализации также пришли в упадок и негодность.

В VII в. раннесредневековая община, жившая уже в значительной мере среди руин, тем не менее могла быть более многочисленной и лучше организованной, чем предполагалось ранее, несмотря на то, что ее материальная культура была значительно хуже по сравнению с предыдущей эпохой. Сагаласс, по всей видимости, существовал как кастрон, оборонительный и административный форпост фемы. В кастроне находилась кафедра епископа, который, возможно, координировал строительство укреплений и другие жизненно важные вопросы [Poblome et al., 2010].

Территория и памятники Сагаласса. Памятники города Салагасса открылись миру благодаря многолетнему успешному проекту бельгийских археологов из Лувенского католического университета. Сагаласс как археологический объект Писидии представляется наиболее репрезентативным в регионе и одним из наиболее ярких памятников Малой Азии.

Городище расположено на большой высоте - в среднем около 1500 м над уровнем моря, с перепадом террас до 300 м и двумя плато - Верхним и Нижним. На юг открывается глубокое ущелье. Современный въезд в город открывается с востока.

Юго-западная часть города, еще не раскопанная территория, по-видимому, содержит самые ранние жилые постройки, включая несколько вероятных эллинистических перистильных домов. Возможно, здесь находится ядро самого раннего поселения. Около 200 г. до н. э. центр Сагаласса, по всей видимости, сместился на север, когда вокруг Верхней Агоры был создан новый политический центр, более подходящий для эллинизированных городских поселений. Ко II в. до н. э. застроенная территория Сагаласса начала расширяться на восток, за пределы укреплений, а также к югу. Возможно, происходит синойкизм с рядом соседних поселений [Waelkens, 2019, p. 4].

В 6 г. до н. э. римлянами была построена важная дорога Виа Себасте, соединившая основные колонии Августа в Писидии с портами Памфилии через Сагаласс [Waelkens, 1997, p. 46]. Она давала городу прямой выход к морю, и элита Сагаласса воспользовалась этой возможностью, вложив огромные средства в смену специализации хоры. Они сожгли большие участки леса и обратили освободившиеся земли в пастбища, поля для выращивания зерновых и оливковые рощи. Климатический оптимум, начавшийся во времена правления Августа и продолжавшийся несколько столетий, позволил выращивать оливки (ранее на высотах до 900 м) теперь вплоть до высоты 1400 м [Waelkens, 2019, p. 7].

В течение большей части римского периода объем производства на хоре Сагаласса значительно превышал жизненные потребности сельского населения, которое, по оценкам, составляло от 6000 до 25000 чел. Излишки продукции, остававшиеся после уплаты налогов натурой (аннона), пошли на торговлю. В результате уровень жизни горожан значительно вырос, отражением чему могут служить многочисленные мавзолеи и дорогие саркофаги, найденные по всей хоре, начиная со времени раннего принципата и далее, в которых владельцы вилл хоронили возле своих поместий [Waelkens, 2019, p. 7-8].

В течение I века город увеличился почти в четыре раза, заняв площадь в 41 га. С этого времени в восточном жилом квартале строились богатые дома в перистиле, даже с частными банями. Это городское развитие потребовало строительства сложных городских 
систем водоснабжения. Начиная с правления Августа, два акведука, один с запада и один с востока соответственно, снабжали водой новый Нижний город на юге и расширяющийся восточный внутренний квартал [Waelkens, 2019, p. 8].

Верхний город. Исторически это был наиболее престижный район города с основными общественными зданиями. Формирование общественного центра происходило при Августе и его преемниках, затем при Антонинах.

Верхняя агора. В первой четверти I в. центр города был полностью застроен монументальными сооружениями. К концу этого века Верхняя Агора эллинистического времени была расширена на запад и увеличена вдвое, заняв площадь $2380 \mathrm{~m}^{2}$. Агора была вымощена незадолго до строительства юго-западной арки, посвященной Калигуле (37-41 гг.) (рис. 3).

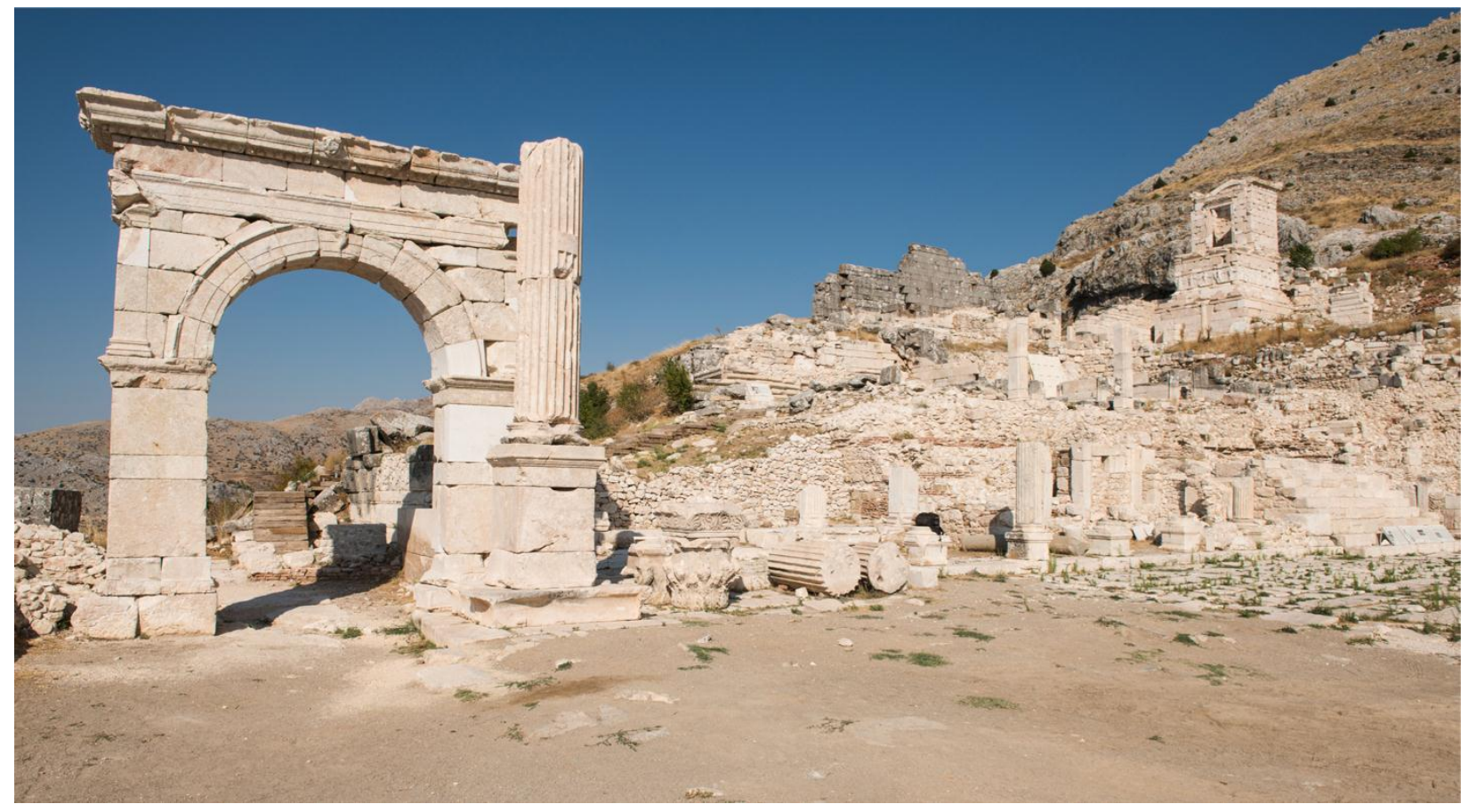

Рис. 3. Арка Калигулы, повторно посвященная Клавдию в 42 г. Справа - пьедестал и нижние барабаны почетной колонны, установленной Демосом в честь Кратера, сына Калликла.

(C) Sagalassos Project [Waelkens, 2015, p. 208]

Fig. 3. The Arch of Caligula rededicated to Claudius in 42 A. D. To the right, the pedestal and lowest drums of the honorific column set up by the Dèmos to honour Krateros, son of Kallikles. (C) Sagalassos Project

Арка была возведена знатным гражданином Калликлом. В 43-46 гг. Клавдию посвятили двойную арку в юго-восточном углу площади, но Калликл снова установил статую Клавдия на вершине монумента. К тому времени семье Калликла было предоставлено римское гражданство. Это были первые сагалассцы, которые стали cives romani. Площадь была обрамлена портиками с запада и востока. По четырем углам Верхней агоры были открыты колонны, на которых предположительно стояли статуи создателей комплекса площади знаменитых жителей города. В 2013 г. была обнаружена последняя, четвертая колонна высотой 12 м и статуя с греческой надписью I в. до н. э. Также была открыта нижняя часть колонны с надписью, посвященной известному Сексту Юлию Фронтину, правителю Малой Азии при Домициане [Lavan, 2013]. K VI веку площадь была преобразована в открытый рынок и, возможно, была более многолюдной, чем когда-либо прежде.

Нимфейон Антонина имеет высоту 9 м, 4 м в ширину и длину 28 м. Был построен на территории Верхней агоры между 161-180 гг. Вода падала с высоты 4,5 м в середине сооружения. Бассейн вмещал 81 кубометр воды. В дополнение к двум статуям Диониса, 
которые стояли по обе стороны фонтана, позже были добавлены и другие. Нимфейон был украшен головами Медузы и мотивами с рыбами. Хотя он обрушился во время землетрясения 590 г., обломки остались на своих местах, что облегчило реставрацию. Сооружение ныне составляет главную часть агоры.

Тихейон. Святилище богини Тихе в Сагалассе - относительно скромный храм с колоннами, был построен во 2-й половине эпохи Августа и занимал заметное место в середине южной стороны Верхней Агоры. Памятник был раскопан в 1992 г. [Talloen, 2019].

Северо-западный Героон был возведен в эпоху Августа около 1 г. на террасе, выходящей на Верхнюю Агору с севера, и доминировал над площадью, возвышаясь над его территорией на 15 м. Фриз героона украшен скульптурным изображением кругового танца в исполнении 15 девушек, держащихся за края одежд друг друга [Корзун, 2020].

Дорический храм был возведен западнее героона в 50-25 гг. до н. э. в честь Зевса [Talloen, 2014]. Между ним и западной стеной героона была установлена колоссальная статуя юноши (3,5 м высотой). В Сагалассе использовался преимущественно дорический ордер.

Булевтерий. В 1-й четверти I в. на склоне между дорическим храмом и расширенной Верхней Агорой возник новый булевтерий; он имел U-образное расположение скамей для 220 членов городского совета. С внешней стороны у булевтерия был фриз с изображением бога войны Ареса и Афины, демонстрирующего военную мощь города. Около 200 г. заседания совета были перенесены в новый Одеон в Нижнем городе.

Позднеантичная фортификация. Около 400 г. была построена новая городская стена, в которую вошли уже заброшенный к тому времени дорический храм и прилегающий к нему северо-западный Героон в качестве башен по обе стороны от новых ворот. Однако она защищала только треть прежней территории Сагаласса. Несмотря на использование сполий, многие из которых происходят из булевтерия и дорического храма, стена была возведена тщательно и по регулярному плану. Это говорит о том, что строительство не было поспешным, вызванным конкретной угрозой, а скорее отражает новую историческую ситуацию [Waelkens, Vandeput etc., 2000].

Северо-Восточный Героон располагался восточнее северо-западного на одной с ним улице (оси).

Пританей. Вскоре после середины I в. отец и дядя вышеупомянутого Калликла, будучи римскими гражданами, профинансировали строительство общественного здания, вероятно, пританея, в юго-западном углу Верхней Агоры. Пританей занимает важное место среди общественных зданий, сыгравших видную роль в жизни римского и позднеантичного Сагаласса. Здание претерпело различные изменения, причем наиболее фундаментальные архитектурные изменения произошли в период с начала V до начала VII в. [Uytterhoeven, Poblome, 2019]. Расположенный непосредственно к югу от булевтерия, он граничит с северной стороной юго-западной улицы, которая входит на Верхнюю Агору через юго-западную арку, посвященную Клавдию и Германику. Хотя в настоящее время нет однозначных эпиграфических или археологических свидетельств, позволяющих с уверенностью определить функцию сооружения, его впечатляющий характер и архитектурные особенности, а также его видное расположение в центре города, рядом с булевтерием, позволяют предположить, что здание могло функционировать как пританей, где работали должностные лица, поддерживался вечный огонь Гестии, организовывалась повседневная жизнь города, происходили приемы посольств и т. д.

Эллинистический нимфейон. На пути к театру в северо-восточном направлении от Верхней Агоры находится неплохо сохранившийся нимфейон, построенный с 50 по 25 гг. до н. э.

Библиотека Неона. Близ эллинистического нимфейона гражданин Т. Флавий Севериан Неон, величайший благотворитель в истории города, построил крупнейшее здание публичной библиотеки для своего покойного отца между 120 и 125 гг. Библиотека претерпела два капитальных ремонта: один на пролете крыши (ок. 200 г.), а другой - в ре- 
зультате объединения комплекса здания с серией колонн (ок. 350-375 г.). Памятник всегда выполнял двойную функцию - публичной библиотеки и памятника в честь семьи строителя (эвергета), сыгравшего новаторскую роль в развитии города и местной политики раннеимперских времен. Эту вторую функцию подчеркивают задняя стена и семь статуй. Считается, что эта необычайная честь, оказанная Севериану Неону, является результатом важной роли города в том, что он был признан неокором Писидии около 117/119 г. [Waelkens, 2015, p. 215-259]. Подиум в задней части декорирован округлыми и прямоугольными нишами для хранения текстов. В краткое правление императора Юлиана была выполнена мозаика сцена «Ахилл отправляется в Трою». Библиотека Неона была сожжена и разрушена христианскими активистами незадолго до рубежа IV-V вв.

Teamp. Театр, заменивший меньшее по размеру аналогичное сооружение и в конечном итоге рассчитанный на 7000 (по другим оценкам - 9000 ) мест, был построен в конце II в. в северо-восточной части Верхнего города. Несмотря на неплохую сохранность, к настоящему времени театр еще не вполне отреставрирован.

Стадион. Вероятно, во время правления Веспасиана (69-96 гг.) гражданин Т. Клавдий Пизон связал культ императора с играми в честь Аполлона Клария, Клареями, которые были учреждены при Нероне и проводились на недавно построенном стадионе в северо-западной части Верхнего города. Пизон стал первым римским всадником города.

Нимфейон Траяна. В 116-117 гг. члены местного сообщества Тибериев Клавдиев посвятили апсидальный нимфейон с отдельно стоящими колоннами городу и императору Траяну у входа на стадион. Нимфейон здесь был построен на деньги Клавдии Северы, ее сестер и братьев, в то время когда она породнилась с другой влиятельной семьей - семьей Неонов. Вход в нимфейон украшали ионические колонны, а вода подавалась из одной из статуй. Позднее на его месте была возведена базилика.

Базилика св. Михаила, у которого было большое количество почитателей в Сагалассе, была построена ниже Верхней агоры. Монументальная лестница, соединяющая Верхнюю Агору непосредственно с церковью, была сооружена во 2-й четверти VI в., что относится к стадии перестройки комплекса в ранневизантийское время.

Нижний город. Оформился несколько позднее Верхнего и всегда уступал ему по престижности, в то же время будучи в большей степени центром деловой активности.

Большая колоннадная улица. Во время правления Тиберия (14-37 гг.) одна из старейших и самых широких улиц Малой Азии с колоннами (9,6-10 м в ширину, 290 м в длину) была завершена и украшена монументальными воротами с обоих концов [Jacobs, Waelkens, 2013]. Полностью пешеходный, этот проспект соединял Нижнюю Агору с Южными воротами. Большинство других улиц этого района также были вымощены в период правления Юлиев-Клавдиев. Вдоль Колоннадной улицы верховный жрец Императорского культа эпохи Северов посвятил большое здание Александру Северу и Юлии Маммее. К VI в. на Колоннадной улице был проведен значительный ремонт, включая частичную замену тротуара и обновление портиков, которые теперь преимущественно состояли из колонн. Реконструкция Колоннадной улицы так и не была полностью завершена [Lavan, 2008].

Ворота Тиберия. При Тиберии в конце и в начале Колоннадной улицы находились монументальные ворота с колоннами. В V веке их разрушило землетрясение. Это был главный вход в город с юга.

Нижняя агора. Нижняя Агора имела более коммерческий характер, чем Верхняя,

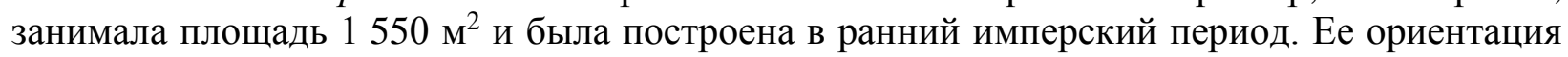
отличалась от Верхней Агоры; она была связана с прямоугольным планом улиц новых южных городских кварталов. Район вокруг Нижней Агоры получил дальнейшее развитие во времена Флавиев и Траяна. Площадь получила ионические портики вдоль длинных сторон. В течение 1-й половины VI в. Нижняя Агора была расширена и лестница, ведущая с Большой Колоннадной улицы, была перенесена на несколько метров к югу [Talloen, 
2019]. На Нижней Агоре до начала VII в. функционировали только таверны в обоих портиках северной стороны [Devijver, Waelkens, 1995; Lavan, 2013].

Нимфейон Адриана. Во время Адриана строительство монументального нимфейона, граничащего с Нижней Агорой на севере, еще больше увеличило монументальность этой площади. Т. Клавдий Пизон, первый римский всадник города, посвятил Адриану это двухэтажное сооружение, завершенное его наследниками в 129-132 гг. Нимфейон имел 17 м в высоту. На нижнем этаже в центре стояла 4-метровая статуя Аполлона. Над ней находилась статуя Адриана, по бокам от которой были статуи, изображавшие самого мецената. Кроме того, тут были статуи наследников Пизона и различных богов. В начале VI в. нимфейон был разрушен и более не восстанавливался. Он был расположен над террасой Нижнего города в завершении Колоннадной улицы [Mägele, Richard, Waelkens, 2007] (рис. 4).

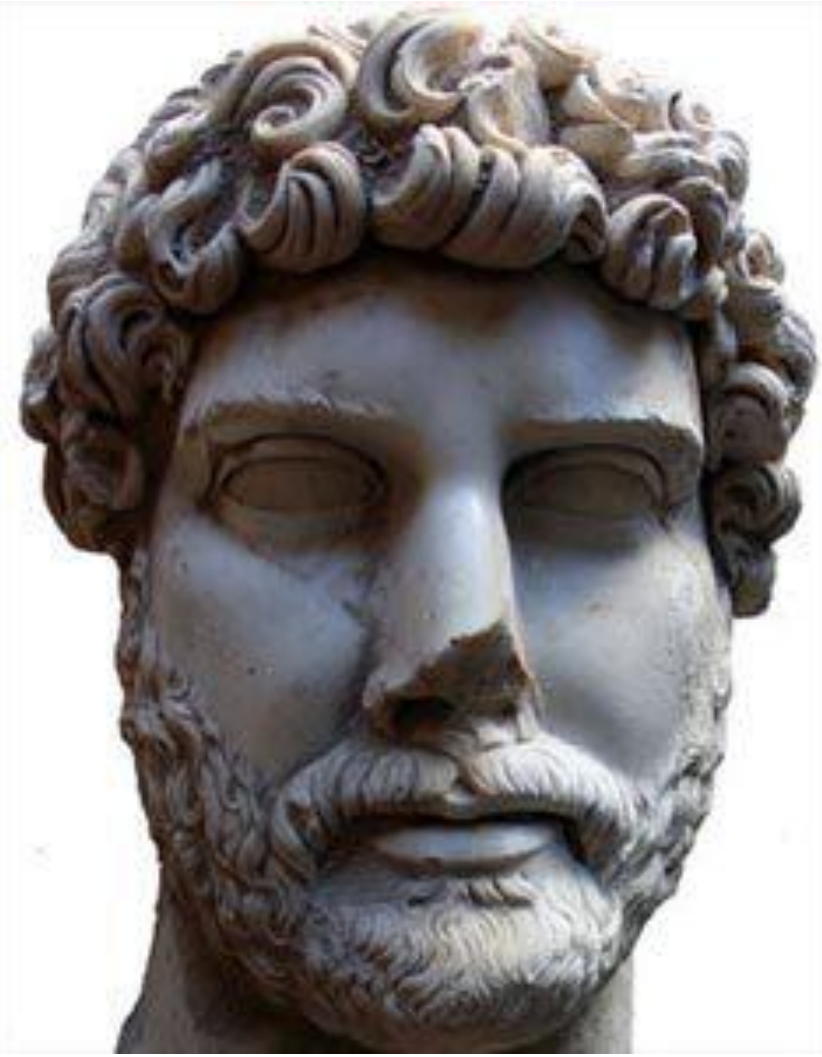

Рис. 4. Голова Адриана из Сагаласса. (C) Sagalassos Archaeological Research Project / Lenta.ru. 29 августа 2008

Fig. 4. Head of Adrian from Sagalassus. (C) Sagalassos Archaeological Research Project / Lenta.ru. $29 / 08 / 2008$

Храм Аполлона Клария. На входе в Нижний город находился храм в честь Аполлона Клария, построенный при Августе на рубеже двух эр [Işın, 2014]. Это был небольшой ионический храм в антах с видом на Нижнюю Агору с запада. При Траяне храм, который к тому времени был связан с муниципальным культом императора, был преобразован в ионический периптер путем добавления внешней колоннады [Приходько, 2014, с. 190191; Talloen, Waelkens, 2004; Talloen, Waelkens, 2005]. K середине V в. заброшенное святилище Аполлона Клария - его целла и перистасис - были восстановлены с внешней стороны и превращены в базилику.

Одеон (булевтений Нижнего города). Строительство одеона близ Агоры было полностью завершено только к III в. и заместило старый зал совета, завершив строительную 
программу Августа в этом районе, которая, скорее всего, финансировались самим городом. Во 2-й половине IV в. сиденья Одеона, который к тому времени, вероятно, использовался как более удобное место для заседаний совета, чем раннеимператорский булевтерий, были подняты на более высокий уровень, на вершину подиума. Это защищало зрителей во время представлений с травлей животных и гладиаторских игр, для которых это здание теперь также было приспособлено.

Рынок продовольственный (Мацеллум). Местные аристократы финансировали строительство сооружений, выполнявших утилитарную функцию для городского сообщества. В их число входил и Мацеллум - продовольственный рынок. Меценатом здесь выступил Публий Элий Акула - богатый житель города и жрец культа императора. Это был рынок дорогих товаров, состоящий из множества торговых лавок, в центре которого располагалось святилище в виде ротонды. Построен он был в конце II в., а до этого на его месте был другой рынок, построенный еще при Августе. Сооружение было посвящено императору Коммоду и его победе над Парфией. Это единственное сооружение в городе с использованием коринфского ордера. Мацеллум претерпел полную реконструкцию в V в., но до 2-й половины VI в. все еще работал как продовольственный рынок, хотя его участки уже использовались для захоронения отходов.

Нимфейон Севера. Нимфейон - важное и хорошо сохранившееся сооружение Нижнего города. Был построен в 160-180 гг. на месте гораздо более простого фонтана периода Августа. При строительстве использовалось 7 видов различного камня и богатый декор дионисийского характера. Длина его 28 м, сохранившаяся высота - 9 м. При раскопках в бассейне были обнаружены статуи, стоявшие в нишах; они были помещены туда в процессе христианизации. В V в. после землетрясения нимфейон был превращен в мемориал в честь одной знатной семьи. После землетрясения VII в. он обрушился и более не восстанавливался.

Императорские термы. В 165 г. к востоку от Нижней агоры были построены термы, посвященные Марку Аврелию и Луцию Веру, площадью 1250 м². Во 2-й пол. VI в. сильное землетрясение разрушило значительную часть города, в том числе термы. Обвалившаяся крыша и стены накрыли полы помещений толстым слоем битого камня и черепицы. В этом завале в июле 2007 г. были найдены фрагменты статуи Адриана: голова (высотой более $70 \mathrm{~cm}$ ), стопа (длиной около $80 \mathrm{~cm}$ ) и правая голень. В августе 2008 г. нашли огромную женскую мраморную голову - высотой 76 см, в 6 м от статуи Адриана, а также фрагмент женской правой руки и фрагменты женских сандалий. Голова оказалась похожа на известный портрет Фаустины Старшей, жены Антонина Пия, происходящий из Сард. Все находки были сделаны в нишах, причем обломки женских статуй находились с восточной стороны, а Адриан - на западной. Следовательно, напротив него должна была стоять статуя Вабии Сабины, его жены, а напротив Фаустины - изваяние ее супруга Антонина Пия. Вскоре были открыты голова, рука и ступни Марка Аврелия, следовательно, напротив должна была находиться статуя Фаустины Младшей, его жены [Waelkens, 2013]. В 2007 г. под императорскими термами II в. был обнаружен самый старый известный римский банный комплекс в Малой Азии - «Старые термы» эпохи Юлиев-Клавдиев.

Городская усадьба. В конце IV - начале V в. две старые перистильные виллы к северо-востоку от Императорских терм стали ядром огромной городской усадьбы - дворца. Она состояла из общественного и частного крыла и из более чем 90 помещений на девяти различных уровнях. Возможно, это была резиденция члена недавно появившейся суперэлиты, состоящей из принципалов, honorati и епископов. Превосходя куриалов по власти и богатству, они использовали свои частные дома, а не общественные здания, для демонстрации своего положения в обществе [Devijver, 1996]. Дворцовые черты усадьбы были усилены роскошными декоративными элементами, такими как мозаичные полы, настенные росписи и скульптуры. Тщательно подобранные декоративные программы подчеркивали образование владельца дома. В то время как члены городского совета и муниципаль- 
ные магистраты по-прежнему несли весьма обременительные финансовые обязанности своей должности, члены этого нового высшего класса получили освобождение от налогов, служа в администрации провинции, приобретая крупные земельные владения за пределами своих родных городов. Не позднее 2-ой половины VI в. городская усадьба утратила свой роскошный облик. Пространства как в частных, так и в официальных помещениях теперь использовались как складские помещения. Самовольные поселенцы обосновались в общественной части, а в конце VI в. большую часть частной части комплекса, по-видимому, занимала гостиница. Облицовка стен и скульптура особняка стали поставлять материал в большую печь для обжига извести, установленную в атриуме [Waelkens, 2019].

Храм императорского культа (Адриана и Антонина Пия) стал крупнейшим святилищем Писидии, в юго-восточной части города. Хотя его строительство началось при Адриане, оно было завершено только при его преемнике, и поэтому храм был посвящен Антонину Пию и его семье.

Церковь на месте одеона (булевтерия). В ранневизантийское время на месте булевтерия в бывшем дворе комплекса была возведена церковь. Некоторые повторно использованные рельефы Афины и Ареса из булевтерия в атриуме церкви фиксируют христианское переосмысление языческих образов. Эти преобразования не были символами победы новой религии; скорее, они отражали постоянную заботу о сохранении эстетического вида города [Tybout, Waelkens, 2014].

Прочие иеркви. Между серединой V и серединой VI вв. в городе и на его окраинах было построено в целом не менее восьми церквей (базилик). Недавно были обнаружены еще два храма, один в восточном предместье и один на периферии, датируемых 2-й половиной VI и началом VII в.

Основная библиография по Сагалассу в настоящее время насчитывает более 120 наименований специальных публикаций с начала 1990-х гг. по настоящее время.

Прежде всего следует выделить 7 выпусков специализированного обобщающего издания «Сагаласс», вводящего в научный оборот основные материалы раскопок [Sagalassos I, 1993; Sagalassos II, 1993; Sagalassos III, 1995; Sagalassos IV, 1997; Sagalassos V, 2000; Sagalassos VI, 2008; Sagalassos, 2014].

Далее следует назвать каталог выставки о Сагалассе, который является едва ли не единственным отдельным изданием о городе [Waelkens, Poblome, 2011], хотя и не заменяет отсутствующую пока итоговую монографию.

Среди отдельных публикаций есть в определенной мере обзорно-обобщающие [Waelkens, 2019, p. 1-32]. Некоторые работы и диссертации обобщают отдельные категории материала - краснолаковую керамику [Degeest, 2000], стекло [Lauwers, 2008], скульптуру [Mägele, 2009], архитектурный декор [Vanderput, 1994], посвящены строительным материалам и строительной технике [Loots, 2001].

Особое внимание уделяется позднеантичному (ранневизантийскому) периоду в широких хронологических рамках IV - нач. VII вв., нашедшему отражение в археологии в виде христианизации и медиевализации материальной культуры и топографии города [Јаcobs, 2015].

В отечественной историографии имеется лишь одна статья о Сагалассе, посвященная истории искусства на материалах героона [Корзун, 2020]. Кроме того, Е.В. Приходько опубликовала большую статью в двух частях о близком к Сагалассу городе Адады [Приходько, 2014; Приходько, 2015], что можно расценивать как первый опыт или как уже наметившуюся тенденцию профессионального освоения отечественными антиковедами регионов Малой Азии, используя свои частные поездки.

Большинство имеющихся на данный момент публикаций посвящено отдельным памятникам или комплексам памятников, открытых на территории города. 


\section{Выводы}

В целом, несмотря на прекрасные результаты и выдающиеся достижения в изучении Сагаласса в течение последних лет в мировой археологии и историографии, необходимы дальнейшие исследования, чтобы уточнить детали топографии и истории города, понять, что произошло в Сагалассе и его окрестностях на финальной стадии его существования. История региональных малоазийских городов иллюстрирует динамизм и гибкость местных общин перед лицом хода истории и перемен. История городов и регионов Малой Азии в римское и ранневизантийское время нуждается в актуализации в отечественной историографии.

\section{Список литературы}

1. Болгов Н.H. 2021. Писидия как регион римско-ранневизантийской Малой Азии. Lavrea IIII. Чтения памяти проф. В.И. Кадеева. Харьков, НТМТ: 98-102.

2. Дройзен И.Г. 1997. История эллинизма. Т. 1. СПб., Наука, Ювента, 450.

3. Корзун А.А. 2020. Скульптурный фриз северо-западного героона в Сагалассе: в поисках семантики и иконографических параллелей. Египет и сопредельные страны. Электронный журнал. № 3: 76-95.

4. Приходько Е.В. 2014. Адады - древний город центральной Писидии. Аристей. X: 181-219.

5. Приходько Е.В. 2015. Адады - древний город центральной Писидии. Часть II. Аристей. XI: 233-282.

6. Прокопенко С.Н. 2018. Новые археологические исследования позднеантичного Сиде. Классическая и византийская традиция. 2018. Белгород, 216-219.

7. Ранович А.Б. 1949. Восточные провинции Римской империи в I-ІІІ вв. М.-Л., АН СССР, 264.

8. Ранович А.Б. 1950. Эллинизм и его историческая роль. М.-Л., АН СССР, 382.

9. Свенцицкая И.С. 1981. Полис и империя: эволюция императорского культа и роль «возрастных союзов» в городах малоазийских провинций I-ІІ вв. Вестник древней истории. № 4: 33-51.

10. Burrell B. 2004. Neokoroi: Greek Cities and Roman Emperors. Brill, XVIII+422.

11. Degeest R. 2000. The Common Wares of Sagalassos. Turnhout, 208.

12. Devijver H. 1996. Local elite, equestrians and senators: a social history of Roman Sagalassos. Ancient Society. № 7: 107-152.

13. Işın G. 2014. The Sanctuaries and the Cult of Apollo in Southern Pisidia. Anadolu/Anatolia, 40: 87-104.

14. Jacobs I., Waelkens M. 2013. Five Centuries of Glory. The North-South Colonnaded Street of Sagalassos in the First and the Sixth Century A.D. Istanbuler Mitteilungen. 63: 219-221.

15. Jones A.H.M. 1971. The Cities of the Eastern Roman Provinces. Oxford, UP, 595.

16. Lauwers V. 2008. The Glass of Sagalassos. Typology and Chronology. Diss. Leuven, 284.

17. Lavan L. 2013. The agorai of Sagalassos in Late Antiquity: an interpretative study. Field Methods and Poat-Excavation Techniques in Late Antique Archaeology. Leiden, 289-353.

18. Lavan L. 2008. The Monumental Streets of Sagalassos in Late Antiquity. Un interpretive studies. La rue dans l'Antiquite. Rennes, 201-215.

19. Levick B. 1967. Roman Colonies in Southern Asia Minor. Oxford, UP, 256.

20. Loots L. 2001. The Building Materials and Building Techniques at Sagalassos, Turkey. Diss. Leuven, 198.

21. Mägele S. 2009. Die Plastischen Bildwerke von Sagalassos. Diss. Leuven, 201.

22. Mägele S., Richard J., Waelkens M. 2007. A Late-Hadrianic nymphaeum at Sagalassos (Pisidia, Turkey): a preliminary report. Istanbuler Mitteilungen. 57: 469-504.

23. Magie D. 1950. Roman Rule in Asia Minor. V. 1. Princeton, UP, 723.

24. Poblome J., Bes P., De Cupere B., Lauwers V., Romanus K., Vionis A., Waelkens M. 2010. Sic transit gloria mundi. Does it really? Wasting Seventh Century A.D. Sagalassos (SW Turkey). Late Roman Coarse Wares, Cooking Wares and Amphorae in the Mediterranean: Archaeology and archaeometry. Comparison between western and eastern Mediterranean. Vol. II. Oxford, UP, 791-801.

25. Prokopenko S. 2021. Transformation of the Urban Environment of Late Antique Perge. Issues of Identity Metamorphoses in Transitional Epochs. Cambridge, Scholar, 74-79. 
26. Talloen P. 2014. Cult in Pisidia: Religious Practice in Southwestern Asia Minor from Alexander the Great to the Rise of Christianity. Studies in Eastern Mediterranean Archaeology X. Leuven, 412.

27. Talloen P. 2019. The Tychaion of Sagalassos: The Cultural Biography of an Emblematic Monument. Istanbuler Mitteilungen. 69: 261-304.

28. Talloen P. 2019. The Upper Agora of Sagalassos During the Late Antique Period: the Transformation of an Ideological Centre. Urbanitas - Changes in Cityscape and Urban Life in Late Antiquity and Early Byzantine Times. Assos in Context of Urban Centres in Western Asia Minor: 3-24.

29. Talloen P., Waelkens M. 2004. Apollo and the Emperors (I). The Material Evidence for The Imperial Cult at Sagalassos. Ancient Society. Vol. 34: 171-216.

30. Talloen P., Waelkens M. 2005. Apollo and The Emperors (II). The Evolution of the Imperial Cult at Sagalassos. Ancient Society. Vol. 35: 217-249.

31. Tybout R., Waelkens M. 2014. The Bouleuterium-Church Complex on the Upper Agora. Architecture, Stratigraphy, Chronology. Sagalassos VII. The Upper and Lower Agora. Final Report on the Buildings Along the Long Sides of the City Squares. Turnhout, Brepols, 56-79.

32. Uytterhoeven I., Poblome J. 2019. The «Prytaneion» of Sagalassos: Unravelling an Architectural and Functional Palimpsest. Anatolica. XLV: 131-157.

33. Uytterhoeven I., Waelkens M. 2014. The Bouleuterium-Church Complex on the Upper Agora. Architecture, Stratigraphy, Chronology. Sagalassos VII. The Upper and Lower Agora. The Porticoes, the Bouleuterion, the Basilica of St. Michaël and the «Northeast Building». Leuven, 113-156.

34. Vanderput L. 1994. The Architectural Decoration at Sagalassos. Local Development within the Framework of Anatolian Architecture. The Imperial Period. Diss. Leuven, 176.

35. Waelkens M. 2011. Erste Stadt Pisidiens, Freund und Bundgenosse der Romer. Neue Forschungen in Sagalassos. Antike Welt. 3: 62-71.

36. Waelkens M. 2015. Hadrian and the «Neokoria» of Sagalassos. Pisidia Yazıları Hac1 Ali Ekinci Armağanı. Pisidian Essays in Honour of Haci Ali Ekinci. Istanbul, 177-214.

37. Waelkens M. 2005. Provincial Capitals and Hinterland Cities. A Dialogue at Sagalassos. Synergia. Festschrift für Friedrich Krinzinger. Vienna: Phoibos-Verlag, 377-386.

38. Waelkens M. 2019. Sagalassos, Archaeology of. Encyclopedia of Global Archaeology. Springer Nature Switzerland AG: 1-32.

39. Waelkens M. 2013. The fate of the colossal statues of Hadrian and other members of the Imperial family from the «Imperial Baths» at Sagalassos during Late Antiquity. Hadrian: Arts, Politics and Economy. London, The British Museum: 62-72.

40. Waelkens M. 2015. The Library of Titus Flavius Severianus Neon at Sagalassos. Pisidian Essays in Honour of Haci Ali Ekinci. Pisidia Yazilari Haci Ali Ekinci Armagana, 215-259.

41. Waelkens M., Jacobs I. 2014. Sagalassos in the Theodosian age. Production and Prosperity in the Theodosian Period. Interdisciplinary Studies in Ancient Culture and Religion, 14. Leuven-Walpole, 91-126.

42. Waelkens M., Poblome J. 2011. Sagalassos. City of Dreams. Gent, 102.

43. Waelkens M., Vandeput L., Berns C., Arıkan B., Poblome J., Torun E. 2000. The Northwest Heroön at Sagalassos. Sagalassos V. Report on the Surveys and Excavation Campaigns of 1996 and 1997. Leuven, University Press, 553-594.

\section{Referenses}

1. Bolgov N.N. 2021. Pisidija kak region rimsko-rannevizantiı̌skoĭ Maloĭ Azii [Pisidia as a region of the Roman-early Byzantine Asia Minor]. Lavrea IIII. Chtenija pamjati prof. V.I. Kadeeva [Lavrea IIII. Readings in memory of prof. V.I. Kadeev]. Har'kov, NTMT: 98-102.

2. Drojzen I.G. 1997. Istorija jellinizma [History of Hellenism]. T. 1. SPb., Nauka, Juventa, 450 (in Russian).

3. Korzun A.A. 2020. Skul'pturnyj friz severo-zapadnogo geroona v Sagalasse: v poiskah semantiki i ikonograficheskih parallelej [Sculptural frieze of the Northwest heroon in Sagalassus: in search of semantics and iconographic parallels]. Egipet i sopredel'nye strany. Jelektronnyj zhurnal [Egypt and neighboring countries. Electronic journal]. № 3: 76-95 (in Russian).

4. Prihod'ko E.V. 2014. Adady - drevnij gorod central'noj Pisidii [Adada - the ancient city of central Pisidia]. Aristej [Aristeas]. X: 181-219 (in Russian).

5. Prihod'ko E.V. 2015. Adady - drevnij gorod central'noj Pisidii [Adada - the ancient city of central Pisidia]. Chast' II [Part 2]. Aristej [Aristeas]. XI: 233-282 (in Russian). 
6. Prokopenko S.N. 2018. Novye arheologicheskie issledovanija pozdneantichnogo Side [New archaeological research of late antique Side]. Klassicheskaja i vizantijskaja tradicija. 2018 [Classical and Byzantine tradition. 2018]. Belgorod, 216-219 (in Russian).

7. Ranovich A.B. 1949. Vostochnye provincii Rimskoj imperii v I-III vv. [Eastern provinces of the Roman Empire in the 1st - 3rd centuries]. M.-L., AN SSSR, 264 (in Russian).

8. Ranovich A.B. 1950. Jellinizm i ego istoricheskaja rol' [Hellenism and its historical role]. M.-L., AN SSSR, 382 (in Russian).

9. Svencickaja I.S. 1981. Polis i imperija: jevoljucija imperatorskogo kul'ta i rol' «vozrastnyh sojuzov» v gorodah maloazijskih provincij I-II vv. [Polis and empire: the evolution of the imperial cult and the role of «age unions» in the cities of Asia Minor provinces in the 1st - 2nd centuries.] VDI [Ancient History Herald]. № 4: 33-51 (in Russian).

10. Burrell B. 2004. Neokoroi: Greek Cities and Roman Emperors. Brill, XVIII+422.

11. Degeest R. 2000. The Common Wares of Sagalassos. Turnhout, 208.

12. Devijver H. 1996. Local elite, equestrians and senators: a social history of Roman Sagalassos. Ancient Society. № 7: 107-152.

13. Işın G. 2014. The Sanctuaries and the Cult of Apollo in Southern Pisidia. Anadolu/Anatolia, 40: 87-104.

14. Jacobs I., Waelkens M. 2013. Five Centuries of Glory. The North-South Colonnaded Street of Sagalassos in the First and the Sixth Century A.D. Istanbuler Mitteilungen. 63: 219-221.

15. Jones A.H.M. 1971. The Cities of the Eastern Roman Provinces. Oxford, UP, 595.

16. Lauwers V. 2008. The Glass of Sagalassos. Typology and Chronology. Diss. Leuven, 284.

17. Lavan L. 2013. The agorai of Sagalassos in Late Antiquity: an interpretative study. Field Methods and Poat-Excavation Techniques in Late Antique Archaeology. Leiden, 289-353.

18. Lavan L. 2008. The Monumental Streets of Sagalassos in Late Antiquity. Un interpretive studies. La rue dans l'Antiquite. Rennes, 201-215.

19. Levick B. 1967. Roman Colonies in Southern Asia Minor. Oxford, UP, 256.

20. Loots L. 2001. The Building Materials and Building Techniques at Sagalassos, Turkey. Diss. Leuven, 198.

21. Mägele S. 2009. Die Plastischen Bildwerke von Sagalassos. Diss. Leuven, 201.

22. Mägele S., Richard J., Waelkens M. 2007. A Late-Hadrianic nymphaeum at Sagalassos (Pisidia, Turkey): a preliminary report. Istanbuler Mitteilungen. 57: 469-504.

23. Magie D. 1950. Roman Rule in Asia Minor. V. 1. Princeton, UP, 723.

24. Poblome J., Bes P., De Cupere B., Lauwers V., Romanus K., Vionis A., Waelkens M. 2010. Sic transit gloria mundi. Does it really? Wasting Seventh Century A.D. Sagalassos (SW Turkey). Late Roman Coarse Wares, Cooking Wares and Amphorae in the Mediterranean: Archaeology and archaeometry. Comparison between western and eastern Mediterranean. Vol. II. Oxford, UP, 791-801.

25. Prokopenko S. 2021. Transformation of the Urban Environment of Late Antique Perge. Issues of Identity Metamorphoses in Transitional Epochs. Cambridge, Scholar, 74-79.

26. Talloen P. 2014. Cult in Pisidia: Religious Practice in Southwestern Asia Minor from Alexander the Great to the Rise of Christianity. Studies in Eastern Mediterranean Archaeology X. Leuven, 412.

27. Talloen P. 2019. The Tychaion of Sagalassos: The Cultural Biography of an Emblematic Monument. Istanbuler Mitteilungen. 69: 261-304.

28. Talloen P. 2019. The Upper Agora of Sagalassos During the Late Antique Period: the Transformation of an Ideological Centre. Urbanitas - Changes in Cityscape and Urban Life in Late Antiquity and Early Byzantine Times. Assos in Context of Urban Centres in Western Asia Minor: 3-24.

29. Talloen P., Waelkens M. 2004. Apollo and the Emperors (I). The Material Evidence for The Imperial Cult at Sagalassos. Ancient Society. Vol. 34: 171-216.

30. Talloen P., Waelkens M. 2005. Apollo and The Emperors (II). The Evolution of the Imperial Cult at Sagalassos. Ancient Society. Vol. 35: 217-249.

31. Tybout R., Waelkens M. 2014. The Bouleuterium-Church Complex on the Upper Agora. Architecture, Stratigraphy, Chronology. Sagalassos VII. The Upper and Lower Agora. Final Report on the Buildings Along the Long Sides of the City Squares. Turnhout, Brepols, 56-79.

32. Uytterhoeven I., Poblome J. 2019. The «Prytaneion» of Sagalassos: Unravelling an Architectural and Functional Palimpsest. Anatolica. XLV: 131-157. 
33. Uytterhoeven I., Waelkens M. 2014. The Bouleuterium-Church Complex on the Upper Agora. Architecture, Stratigraphy, Chronology. Sagalassos VII. The Upper and Lower Agora. The Porticoes, the Bouleuterion, the Basilica of St. Michaël and the «Northeast Building». Leuven, 113-156.

34. Vanderput L. 1994. The Architectural Decoration at Sagalassos. Local Development within the Framework of Anatolian Architecture. The Imperial Period. Diss. Leuven, 176.

35. Waelkens M. 2011. Erste Stadt Pisidiens, Freund und Bundgenosse der Romer. Neue Forschungen in Sagalassos. Antike Welt. 3: 62-71.

36. Waelkens M. 2015. Hadrian and the «Neokoria» of Sagalassos. Pisidia Yazılar1 Hac1 Ali Ekinci Armağanı. Pisidian Essays in Honour of Haci Ali Ekinci. Istanbul, 177-214.

37. Waelkens M. 2005. Provincial Capitals and Hinterland Cities. A Dialogue at Sagalassos. Synergia. Festschrift für Friedrich Krinzinger. Vienna: Phoibos-Verlag, 377-386.

38. Waelkens M. 2019. Sagalassos, Archaeology of. Encyclopedia of Global Archaeology. Springer Nature Switzerland AG: 1-32.

39. Waelkens M. 2013. The fate of the colossal statues of Hadrian and other members of the Imperial family from the «Imperial Baths» at Sagalassos during Late Antiquity. Hadrian: Arts, Politics and Economy. London, The British Museum: 62-72.

40. Waelkens M. 2015. The Library of Titus Flavius Severianus Neon at Sagalassos. Pisidian Essays in Honour of Haci Ali Ekinci. Pisidia Yazilari Haci Ali Ekinci Armagana, 215-259.

41. Waelkens M., Jacobs I. 2014. Sagalassos in the Theodosian age. Production and Prosperity in the Theodosian Period. Interdisciplinary Studies in Ancient Culture and Religion, 14. Leuven-Walpole, 91-126.

42. Waelkens M., Poblome J. 2011. Sagalassos. City of Dreams. Gent, 102.

43. Waelkens M., Vandeput L., Berns C., Arıkan B., Poblome J., Torun E. 2000. The Northwest Heroön at Sagalassos. Sagalassos V. Report on the Surveys and Excavation Campaigns of 1996 and 1997. Leuven, University Press, 553-594.

Конфликт интересов: о потенциальном конфликте интересов не сообщалось. Conflict of interest: no potential conflict of interest related to this article was reported.

\section{ИНФОРМАЦИЯ ОБ АВТОРАХ}

Болгов Николай Николаевич, доктор исторических наук, профессор кафедры всеобщей истории Белгородского государственного национального исследовательского университета, г. Белгород, Россия

Елисеева Анастасия Юрьевна, кандидат исторических наук, старший научный сотрудник Белгородского государственного историкокраеведческого музея, г. Белгород, Россия

\section{INFORMATION ABOUT THE AUTHORS}

Nikolay N. Bolgov, doctor of Historical Sciences, Professor of the Department of General History, Belgorod State National Research University, Belgorod, Russia

Anastasia Yu. Eliseeva, candidate of Historical Sciences, Senior Researcher, Belgorod State Museum of History and Local Lore, Belgorod, Russia 